\title{
IDENTIFIKASI KUALITAS INTERNAL TELUR DAN FAKTOR PENURUNAN KUALITAS SELAMA PENYIMPANAN
}

\section{IDENTIFICATION OF THE INTERNAL QUALITY OF EGGS AND FACTORS OF DECREASING QUALITY DURING STORAGE}

\author{
Woki Bilyaro $^{1)}$, Dian Lestari ${ }^{1)}$, dan Ayu Sri Endayani ${ }^{2)}$ \\ ${ }^{1)}$ Dosen Program Studi Nutrisi dan Teknologi Pakan Ternak, Fakultas Pertanian dan \\ Peternakan, Universitas Muhammadiyah Kotabumi, Lampung Utara, Lampung \\ ${ }^{2)}$ Mahasiswa Program Studi Nutrisi dan Teknologi Pakan Ternak, Fakultas Pertanian \\ dan Peternakan, Universitas Muhammadiyah Kotabumi, Lampung Utara, \\ Lampung \\ E-mail:woki.bilyaro@umko.ac.id
}

\begin{abstract}
Eggs are one of the cheap food that contains complete nutritions and is needed by the human body. Eggs are easily daemaged physically, chemically and microbiologically. Prolonged storage, temperature storage and clean storage of eggs can effect eggs quality. This study aimed to know the effect of prolonged storage on eggs quality in the community. This research was conducted by purposive sampling method by analyzing chicken eggs stored by the community at room temperature with different storage periods, namely 1 day, 5 days, 10 days, and 14 days. Each treatment length of storage consisted of 5 replications, and each replication consisted of 3 eggs. The total number of chicken eggs used was 60 eggs. Storage periods can affect the value of $H U$, pH of eggs, and the enlargement of air pockets. Based on studies show that the best eggs are $4-7^{\circ} \mathrm{C}$. Eggs should be stored in a clean storage avoid the growth of pathogenic microorganisms. Eggs should be kept separate from other food ingredients (vegetables and fruits). Several technologies can be utilized to maintain eggs quality. These technologies include pasteurization technology, Extremely Low-Frequency Magnetic Fields (ELF-MF), Thyme Oil and Cold Nitrogen Plasma (CNP) and Dielectric Barier Discharge-UV Plasm. Based on Indonesian National Standar (SNI), eggs can be stored at room temperature a maximum for 14 days with $80 \%$ - $90 \%$ of humidity and a maximum 30 days at $4-7^{\circ} \mathrm{C}$ temperature with $60 \%$ - $70 \%$ of humidity.
\end{abstract}

Keyword: Egg quality, storage periods, $H U$ value, $p H$ egg

\begin{abstract}
Abstrak: Telur merupakan salah satu bahan makanan dengan harga ekonomis yang memiliki nilai gizi lengkap dan dibutuhkan oleh tubuh. Telur mudah mengalami kerusakan baik secara fisik, kimia dan mikrobiologis. Durasi waktu penyimpanan dapat mempengaruhi kualitas telur. Tujuan penelitian: Tujuan penelitian ini adalah untuk mengetahui pengaruh durasi waktu penyimpanan terhadap perubahan kualitas telur dimasyarakat. Penelitian ini dilakukan dengan metode purposive sampling dengan cara menganalisis telur ayam yang disimpan oleh masyarakat pada suhu ruang dengan durasi waktu penyimpanan yang
\end{abstract}


berbeda yakni 1 hari, 5 hari, 10 hari, dan 14 hari. Masing-masing perlakuan lama simpan terdiri dari 5 ulangan, dan setiap ulangan terdiri dari 3 butir telur. Total telur ayam ras yang digunakan sebanyak 60 butir telur. Durasi waktu penyimpanan dapat mempengaruhi nilai $\mathrm{HU}, \mathrm{Ph}$ telur, dan perbesaran kantong udara. Berdasarkan kajian menunjukkan bahwa telur terbaik adalah disimpan pada suhu antara $4-7^{\circ} \mathrm{C}$. Beberapa metode yang dapat dimanfaatkan dalam upaya pengawetan telur. Metode tersebut diantaranya adalah metode pasteurisasi, Extremely Low Frequency Magnetic Fields (ELF-MF), Thyme Oil and Cold Nitrogen Plasma (CNP) dan Dielectric Barier Discharge-UV Plasma. Berdasarkan Standar Nasional Indonesia (SNI), Telur dapat disimpan disuhu ruang, maksimum selama 14 hari dengan kelembapan 80\%-90\%. Penyimpanan disuhu 4$7^{\circ} \mathrm{C}$, maksimum selama 30 hari dengan kelembapan 60\%-70\%.

Kata kunci: Kualitas Telur, Lama Simpan, Nilai HU, pH Telur

\section{PENDAHULUAN}

Kesadaran masyarakat Indonesia akan pentingnya asupan nutrisi dalam memenuhi kebutuhan untuk menunjang kehidupan sehari-hari, menyebabkan terjadinya peningkatan konsumsi bahan makanan, terutama bahan makanan sumber protein. Telur adalah salah satu bahan pangan asal hewan yang memiliki harga terjangkau. Fenomena ini mendorong para peternak untuk meningkatkan produk hasil peternakan untuk menunjang permintaan pasar (Tel, dkk. 2021). Telur memiliki nilai gizi yang lengkap yang dibutuhkan oleh tubuh dan juga mudah dicerna. Jumlah konsumsi telur lebih besar daripada hasil ternak lainnya, karena mudah diperoleh dan harganya relatif ekonomis, sehingga terjangkau bagi anggota masyarakat yang mempunyai daya beli rendah (Saliem, 2009).

Menurut Kusnadi (2007), Telur ayam memiliki komposisi kimia yang terdiri dari air $73,6 \%$, protein $12,8 \%$, lemak 11,8\%, Karbohidrat 1,0\% dan komponen lainya $0,8 \%$. Selain itu, telur merupakan salah satu produk unggas yang memiliki asam amino esensial seperti lisin, triptoan, dan khususnya metionin yang merupakan asam-asam amino esensial terbatas (Yuwanta, 2010). Ketersediaan telur ayam yang banyak ditengah masyarakat, tidak diikuti dengan cara penyimpanan yang baik. Keterbatasan pengatahuan masyarakat tentang cara yang baik dalam menyimpan telur, seperti durasi waktu penyimpanan, suhu penyimpanan, kebersihan tempat penyimpanan, sehingga masyarakat tidak terlalu memerhatikan hal tersebut. 
Kondisi akibat penyimpanan telur seperti penyusutan kualitas telur, durasi waktu penyimpanan, dan suhu terbaik penyimpanan telur belum banyak diketahui oleh masyarakat. Seperti yang kita ketahui bahwa telur ayam merupakan bahan pangan yang bergizi tinggi, namun bila tidak diimbangi dengan cara penanganan yang baik terutama dalam hal penyimpanan, telur akan cepat rusak dan akan mengakibatkan penyusutan kualitas internal telur. Penyusutan kualitas telur akibat durasi waktu penyimpanan yang dapat dijadikan indikasi rusaknya telur meliputi besarnya kantung udara, peningkatan derajat keasaman, aroma isi telur dan menurunnya kekentalan albumin. Telur dengan kualitas terbaik adalah telur yang baru saja ditelurkan. Kualitas telur semakin menurun seiring dengan bertambahnya durasi waktu simpan. Sudaryani (2003), menambahkan bahwa seiring dengan lamanya penyimpanan maka telur akan mengalami perubahan kualiatas dan perbesaran kantong udara. Dari permasalahan tersebut diharapkan dengan tulisan ini dapat memberikan informasi kepada masyarakat tentang cara penanganan telur ayam komsumsi terutama dalam hal penyimpanan. Sehingga, telur yang diperoleh pasar maupun langsung dari peternak dapat ditangani dengan baik sesuai dengan standar penyimpanan telur yang telah ditentukan.

\section{METODE}

Pengamatan ini dilakukan dengan metode purposive sampling dengan cara menganalisis telur ayam yang disimpan oleh masyarakat pada suhu ruang dengan durasi waktu penyimpanan yang berbeda yakni 1 hari, 5 hari, 10 hari, dan 14 hari. Masing-masing perlakuan lama simpan terdiri dari 5 ulangan, dan setiap ulangan terdiri dari 3 butir telur. Total telur ayam ras yang digunakan sebanyak 60 butir telur.

\section{HASIL DAN PEMBAHASAN}

Berdasarkan hasil pengamatan pada pada nilai $\mathrm{HU}, \mathrm{pH}$ telur, dan kantog udara diketahui data yang ditampilkan pada Tabel 1.

\section{Durasi waktu penyimpanan}

Telur merupakan produk pangan sumber protein asal ternak ayam yang memiliki masa simpan yang tidak terlalu lama atau terbatas, Lama masa penyimpanan dapat mempengaruhi kualiatas telur. Semakin tinggi umur simpan maka kualitas telur akan semakin menurun. Penyimpanan selama 
1, 5, 10 dan 14 hari nyata memberikan pengaruh terhadap kualitas telur dan perbesaran kantong udara. Hal ini didukung oleh Nova (2013), penyimpanan 5, 10, dan 15 hari akan memberikan pengaruh terhadap penurun berat telur, penyusutan nilai $\mathrm{HU}$, dan peningkatan $\mathrm{pH}$ telur. Penyusutan berat telur biasanya akan berbanding lurus dengan durasi waktu penyimpanan dan perbesaran kantong udara. Semakin lama disimpan, berat telur akan semakin ringan dan kantung udara semakin membesar. Menurut Kurtini dkk. (2011) penyusutan berat telur borkorelasi positif dengan waktu penyimpanan dan pembesaran kantong udara dengan kondisi lingkungan yang konstan. Penyusutan kualitas internal telur akibat dari lamanya penyimpanan dapat diketahui dari ukuran kantung udara udara, $\mathrm{pH}$ telur, dan diameter albumin. Semakin lama telur disimpan maka ukuran kantung udara akan semakin meningkat.

Tabel 1. Pengaruh lama simpan terhadap kualitas internal telur

\begin{tabular}{|l|c|c|c|}
\hline Lama Simpan & Nilai HU & $\mathrm{pH} \mathrm{Telur}$ & Kantong Udara \\
\hline 1 hari & $90,2^{\mathrm{d}}$ & $6,06^{\mathrm{c}}$ & Kecil \\
\hline 5 hari & $77,5^{\mathrm{c}}$ & $6,50^{\mathrm{b}}$ & Kecil \\
\hline 10 hari & $54,1^{\mathrm{b}}$ & $7,00^{\mathrm{a}}$ & Sedang \\
\hline 14 hari & $44,8^{\mathrm{c}}$ & $7,21^{\mathrm{a}}$ & Besar \\
\hline
\end{tabular}

Keterangan : Superskrip yang berbeda pada kolom yang sama menunjukan perbedaan nyata

Menurut Samli dkk. (2005) ukuran kantung udara udara telur akan semakin membesar dikarenakan semakin lamanya penyimpanan. Kantung udara udara telur terbentuk sesaat setelah peneluran sebagai akibat dari adanya perbedaan antara suhu tubuh tubuh induk dengan suhu ruang yang lebih rendah (Jazil, 2013). Lamanya waktu penyimpanan berkorelasi positif dengan meningkatnya nilai $\mathrm{pH}$ pada telur.
Pada minggu pertama $\mathrm{pH}$ telur berkisar diangka 7, minggu ke 2 naik menjadi 8 dan mencapai 9,5 setelah dari 2 minggu penyimpanan. Namun $\mathrm{pH}$ telur pada pengamatan ini lebih rendah yakni 6,06 pada penyimpanan 1 hari dan meningkat 7,21 pada penyimpanan 14 hari.

\section{Nilai HU dan pH telur}

Nilai HU merupakan parameter nilai kesegaran albumin. Penyimpanan 
1 hari pada observasi ini menunjukkan albumin tergolong kualitas sangat baik. Hal ini karena kondisi telur masih segar,sehingga evaporasi $\mathrm{CO}_{2}$ dan $\mathrm{H}_{2} \mathrm{O}$ masih relative rendah serta kekentalan albumin masih baik sehingga nilai HU masih tinggi. Begitu pula seiring bertambahnya lama simpan maka nilai HU dan kekentalan albumin semakin rendah. Evaporasi gas $\mathrm{CO}_{2}$ dan $\mathrm{H}_{2} \mathrm{O}$ pada telur tidak hanya mempengaruhi tingkat kekentalan albumin namun juga meningkatkan $\mathrm{pH}$ pada telur. Hasil penelitian menunjukkan semakin durasi waktu penyimpanan maka semakin tinggi $\mathrm{pH}$ telur yakni 6,06 pada penyimpanan 1 hari dan meningkat menjadi 7,21 pada penyimpanan 14 hari. Tingginya tingkat evaporasi selama penyimpanan juga ditandai dengan perbesaran kantong udara dalam telur. semakin besar evaporasi maka semakin besar kantong udara.

\section{Faktor-faktor yang mempengaruhi kualitas internal telur}

\section{a. Suhu Penyimpanan}

Pada umumnya masyarakat kebanyakan menyimpan telur pada suhu ruang. Selama pengamatan, suhu tempat penyimpanan rata-rata berksar $25-29^{\circ} \mathrm{C}$. Penyimpanan telur pada suhu ruang akan mempercepat evaporasi udara dan air sehingg telur akan mengalami penyusutan kualitas secara cepat. Prinsip utama pada penyimpanan telur adalah mencegah atau memperkecil evaporasi udara dan air dari dalam telur, oleh karena itu penting sekali untuk memperhatikan suhu dan tempat penyimpanan telur agar evaporasi berlangsung lambat.

Menurut standar Joint Commision International (2013) suhu penyimpanan yang optimal telur adalah berkisar antara $4-10^{\circ} \mathrm{C}$, jika disimpan di suhu diatas atau dibawah suhu tersebut akan memberikan pengaruh yang tidak baik terhadap kualitas telur. Suradi (2006) menambahkan bahwa penyimpanan telur terbaik adalah pada suhu 5-10 C atau suhu refrigerasi, karena kualitas telur akan terjaga selama waktu penyimpanan. Telur yang disimpan selama 14 - 15 hari dengan suhu tersebut hanya akan mengalami peningkatan kantung udara dan penyusutan berat telur sebesar 1,79\%. sebagaimana bahan makanan lainnya, telur sebaiknya disimpan pada suhu dibawah $7^{\circ} \mathrm{C}$ (Arisman, 2012).

\section{b. Tempat Penyimpanan}

Penyimpanan bahan makanan seperti telur, sangat perlu sekali memerhatikan kebersihan tempat. Telur yang disimpanan yang tidak baik akan 
mengakibatkan perkembangbiakan atau pertumbuhan mikroorganisme pathogen yang akan menurunkan kualitas telur dan juga berbahaya bagi kesehatan yang mengonsumsinya.

Telur sebaiknya disimpan terpisah dari bahan makanan lainya dan penyimpanan yang optimal telur adalah berkisar antara 4-10 C (JCI, 2013). Telur merupakan bahan makanan yang memiliki nilai nutrisi yang tinggi, namun telur rentan terhadap kerusakan baik secara fisik maupun kimia, terutama kerusakan akibat mikroba (Salmonella sp. dan E. Coli) (Kalfat dkk., 2015). Pemanfaatan metode dalam upaya pengawetan telur telah banyak dilakukan. Metode pada pengawetan telur diperlukan agar kualitas telur segar dapat dipertahankan atau disimpan dalam jangka waktu yang lebih lama (Widyastuti, 2018). Ada banyak tersedia metode yang dapat digunakan dalam mempertahankan kesegaran telur diantaranya metode pasteurisasi (Koswara, 2009), Extremely Low Frequency Magnetic Fields (ELF-MF) (Sudarti, 2016), Thyme Oil and Cold Nitrogen Plasma (CNP) (Cui, dkk., 2016) dan Dielectric Barier DischargeUV Plasma (Widyastuti, 2018). Semua metode tersebut dapat dimanfaatkan untuk mempertahan kulitas telur. Akan tetapi metode-metode tersebut tentu mempunyai kelebihan dan kekurangannya masing-masing.

\section{Standar Telur Ayam Konsumsi}

\section{Berdasarkan Standar Nasional}

Indonesia

Badan Standar Nasional (BSN) telah menetapkan standar nasional Indonesia terhadap kualitas telur ayam komsumsi, termasuk dalam penyimpanan telur. Standar ini digunakan dibuat dengan tujuan memberikan informasi kepada masyarakat tentang standarisasi telur ayam baik yang berasal dari ayam ras maupun ayam kampong, yang layak untuk konsumsi oleh masyarakat.

Menurut BSN (2008), Telur konsumsi yang disimpan disuhu ruang, maksimum dapat disimpan selama 14 hari setelah ditelurkan, dengan kelembapan berkisar antara $80 \%-90$ $\%$. Sedangkan, penyimpanan disuhu $4 \mathrm{C}$ - 7 C dengan kelembapan 60\% - 70\%, telur dapat disimpan maksimum selama 30 hari setelah ditelurkan.

\section{PENUTUP}

\section{a. Simpulan}

Berdasarkan dari uraian diatas dapat disimpulkan bahwa:

1. Durasi waktu penyimpanan dapat mempengaruhi kualitas 
telur

2. Beberapa kajian menyatakan suhu penyimpanan telur segar terbaik adalah pada 4-7 C.

3. Tersedia banyak ternologi dalam upaya mempertahankan kesegaran telur seperti metode pasteurisasi, Extremely Low Frequency Magnetic Fields (ELF-MF), Thyme Oil and Cold Nitrogen Plasma (CNP) dan Dielectric Barier Discharge-UV Plasma.

\section{b. Saran}

Telur sebaiknya disimpan ditempat yang bersih untuk menghindari perkambangbiakan mikroorganisme pathogen yang berbahaya bagi kesehatan yang mengonsumsi.

\section{DAFTAR PUSTAKA}

Arisman. (2012). Buku Ajar Ilmu Gizi Keracunan Makanan. Jakarta: EGC.

Badan Standarisasi Nasional (BSN). (2008). SNI 3926:2008 Telur Ayam Konsumsi. BSN, Jakarta.

Cui, H, Cuixia M., Changzhu L., \& Lin. (2016). "Enhancing The Antibacterial Activity of Thyme Oil Against Salmonella on Eggshell by Plasma-Assited
Process". Journal Of Food Control 70, 183-19.

Jazil,N., Hintono, A., \& Mulyani, S. (2013). "Penyusutan Kualitas Telur Ayam Ras dengan Intensitas Warna coklat kerabang berbeda selama waktu penyimpanan". Jurnal Aplikasi Metode Pangan. Vol. 2 No. 1.

Joint Commission International. (2013). Joint Commission International Accreditation Standards for Hospitals. Retrieved from: http://www.jointcommissionintern ational. org/

Kalfat, A. J. J., \& Zubaidah, E. (2015). "Iradiasi Sinar Gamma pada Telur Ayam Broiler sebagai Upaya Peningkatan Keamanan Pangan (Kajian Dosis Iradiasi dan Penyimpanan Suhu 4 O C)". Jurnal Pangan dan Agroindustri 3, 14381445 .

Koswara, S. (2009). Metode Pengolahan Telur. Universitas Muhammadiyah Semarang, Semarang.

Kurtini, T., Nova, K ., \& D. Septinova. (2011). Produksi Ternak Unggas. Universitas Lampung, Bandar Lampung.

Kusnadi. (2007). Sifat Listrik Telur Ayam Kampung selama waktu penyimpanan.

(Skripsi). 
Departemen Fisika. Fakultas

Matematika dan Ilmu

Pengetahuan Alam. Institut

Pertanian Bogor, Bogor.

Nova, I., Kurtini, T., Wanniatie, \& V. (2013). Pengaruh Durasi waktu penyimpanan terhadap Kualitas Internal Telur Ayam Ras Pada Fase Produksi Pertama. (Skripsi). Universitas Lampung, Bandar Lampung.

Samli, H. E., Agma, A., \& Senkoylu, N. (2005). "Effects of Storage Time and Temperature on Egg Quality in Old Laying Hens". $J$. Appl.Poult Res. 14:548-553.

Saliem, H. P. (2009). Laporan Hasil Penelitian: Analisis Ketahanan Pangan Tingkat Rumah Tangga dan Regional. Bogor: Pusat Penelitian dan Pengembangan Sosial Ekonomi Pertanian.

Sudarti. (2016). "Utilization of Extremely Low Frequency (ELF) Magnetic Field is as Alternative Sterilization of Salmonella Typhimurium in Gado-Gado". Journal of Agriculture and Agricultural Science Procedia. Vol. 9.

Sudaryani. (2003). Kualitas Telur. Penebar Swadaya, Jakarta.

Suradi, K. (2006). "Perubahan Kualitas Telur Ayam Ras dengan Posisi
Peletakan Berbeda selama waktu penyimpanan Suhu Refrigerasi”. Jurnal Ilmu Ternak. Vol. 6 (2): 136-139.

Tel, B. J., Lestari, D., Endayani, A. S., Lase, J. A., \& Ardiarini, N. (2021). "Efek Curcuma dan Allium Sativum terhadap Kadar Lemak Abdomen dan Kolesterol Darah Ayam Ras Pedaging”. Journal of Agriculture And Animal Science. Vol. 1 (1) : 1118.

Widyastuti. E., \& Daydeva, A. (2018). Aplikasi Metode Dielectric Barrier Discharge-Uv Plasma Terhadap Sifat Fisik Dan Kimia Telur Ayam (Gallus Gallus Domesticus). Jurnal Buana Sains. Vol. 18 (1) : 85-96.

Yuwanta, T. (2010). Pemanfaatan Kerabang Telur. Program Studi Ilmu dan Industri Peternakan. Fakultas Peternakan. Universitas Gajah Mada. Yogyakarta 